\title{
Impact of coronavirus disease 2019 (COVID-19) pandemic isolation measures on the rate of non-COVID-19 infections in hematology patients
}

\author{
Jemima H. Miller BA, MBBS, MA ${ }^{1}$ (1), Stephen S. Opat MBBS, FRACP, FRCPA ${ }^{1,2}$, \\ Jake Shortt BMedSc, MBChB, FRACP, FRCPA, PhD ${ }^{1,2}$, Despina Kotsanas BSc(Hons), MClinEpi, FASM ${ }^{3}$, \\ Claire Dendle MBBS, FRACP, GCHPE, PhD ${ }^{2,3}$ and Maryza Graham MBBS, FRACP, FRCPA ${ }^{2,3,4,5}$ \\ ${ }^{1}$ Department of Hematology, Monash Health, Melbourne, Victoria, Australia, ${ }^{2}$ Monash University School of Clinical Sciences, Monash Health, Victoria, Australia, \\ ${ }^{3}$ Department of Infectious Diseases, Monash Health, Melbourne, Victoria, Australia, ${ }^{4}$ Department of Microbiology, Monash Pathology, Monash Health, Victoria, \\ Australia and ${ }^{5}$ Microbiological Diagnostic Unit Public Health Laboratory, The Peter Doherty Institute for Infection and Immunity, The University of Melbourne, \\ Victoria, Australia
}

Laws concerning social distancing and restrictions on public life have been implemented globally during the COVID-19 pandemic. In turn, hospitals have changed their practice, from reduced visitation hours to stronger emphasis on hand hygiene. It would not be surprising, therefore, if transmission of non-COVID-19 infections were to decrease during this time, and data have started to emerge to support reduced incidence. ${ }^{1}$

In this study, we aimed to assess whether the incidence of non-COVID-19 infections had changed in a population of hematology patients while they have been subject to changes in infection control practices during the COVID-19 pandemic (Appendix 1 online). The hematology patient cohort was selected for the study population because they are often more susceptible to infections (from underlying disease or treatment), which, in turn, can result in higher rates of morbidity and mortality. ${ }^{2}$ The outcomes of this study will be used to inform continuation of isolation and infection control measures as the pandemic continues to evolve and afterward.

\section{Methods}

Monash Health is a large, tertiary-care health network in southeastern Australia with a 32-bed hematology inpatient service. Hematology inpatients admitted between January 24 and May 23 (inclusive) for 2019 and 2020 were included in the study, a 4-month period from when the first patient with COVID-19 in Australia was admitted to Monash Health (January 24, 2020) and the equivalent dates the year prior to minimize effects of seasonal variation. Typical presentations for hospital admission included febrile neutropenia and elective inpatient chemotherapy.

All respiratory pathogen polymerase chain reaction (PCR), fecal pathogen PCR, and blood culture results from the cohorts were collated, and the proportion and breakdown of positive

Author for correspondence: Maryza Graham, Monash Medical Centre, 246 Clayton Road, Clayton, Melbourne, Victoria, 3168, Australia. E-mail: Maryza.Graham@ monashhealth.org

Cite this article: Miller JH, et al. (2021). Impact of coronavirus disease 2019 (COVID-19) pandemic isolation measures on the rate of non-COVID-19 infections in hematology patients. Infection Control \& Hospital Epidemiology, 42: 233-235, https:// doi.org/10.1017/ice.2020.1279 results were analyzed. Multiplex PCR assays (AusDiagnostics, Mascot, Australia) included targets for pathogens (Appendix 2 online). The rates of infection for each year were compared using the $\chi^{2}$ test or the Fisher exact as required. Statistical significance was set at $P<.05$. Statistical analyses were performed using Stata version 12.1 software (StataCorp LP, College Station, TX).

Any organism identified more than once in an individual patient within 7 days was considered a duplicate result. Regarding blood cultures, some organisms (listed in Appendix 2 online) were defined as contaminants if they were isolated in a single culture, but they were defined as pathogens if they were isolated in $>1$ culture within 7 days in the same patient.

\section{Results}

Overall, 1,598 patients were admitted in the 2019 date range and 1,488 were admitted in 2020 . The difference in infection rates was statistically significant for respiratory PCR $(20.27 \%$ vs $10.90 \%$; $P=.01)$ but not for fecal PCR $(8.00 \%$ vs $6.76 \% ; P=1.00)$ or blood cultures $(3.27 \%$ vs $3.41 \% ; P=.88)$ (Table 1$)$.

Respiratory PCR virus swabs were procured in patients with respiratory infective symptoms and/or fever, and asymptomatic patients were not routinely tested. In 2019, 22 of the swabs were taken in the first 48 hours of presentation, and 24 were taken in 2020. The incidence of respiratory virus infection was lower in 2020 with 29 of $143(20.27 \%)$ positive tests in 2019 compared to 29 of $266(10.90 \%)$ in $2020(P=.01)$. No cases of COVID-19 were identified. The incidence of all respiratory viruses was lower in 2020 except for respiratory syncytial virus and rhinovirus/enterovirus (Table 1).

There was no significant difference in the incidence of fecal pathogens, with 6 of 75 positive tests $(8.00 \%)$ in 2019 compared to 5 of $74(6.76 \%)$ in $2020(P=.77)$. The rates of positive blood cultures were similar, with 27 of 826 positive isolates $(3.27 \%)$ in 2019 compared with 28 of $822(3.41 \%)$ in $2020, P=.88$. Gram-negative bacilli were isolated in 19 positive blood cultures in both years. Excluding skin flora isolates, gram-positive organisms were isolated in 8 blood cultures in 2019 and 7 in 2020.

(c) The Author(s), 2020. Published by Cambridge University Press on behalf of The Society for Healthcare Epidemiology of America. This is an Open Access article, distributed under the terms of the Creative Commons Attribution licence (http://creativecommons.org/licenses/by/4.0/), which permits unrestricted re-use, distribution, and reproduction in any medium, provided the original work is properly cited. 
Table 1. Breakdown of Microbiology Results by Type

\begin{tabular}{|c|c|c|c|}
\hline \multirow[b]{2}{*}{ Variable } & \multicolumn{2}{|c|}{ Year } & \multirow{3}{*}{$\begin{array}{l}P \\
\text { Value }\end{array}$} \\
\hline & 2019 & 2020 & \\
\hline No. of hematology admissions & 1,598 & 1,488 & \\
\hline $\begin{array}{l}\text { Positive respiratory PCR results as } \\
\text { a percentage of total respiratory } \\
\text { PCR samples taken from hematology } \\
\text { patient cohort }\end{array}$ & $\begin{array}{l}29 \text { of } 143 \\
(20.27)\end{array}$ & $\begin{array}{l}29 \text { of } 266 \\
(10.90)\end{array}$ & .01 \\
\hline Human metapneumovirus & 2 & 0 & \\
\hline Influenza $A / B$ virus & 9 & 5 & \\
\hline Parainfluenza virus-1/-2/-3/-4 & 6 & 0 & \\
\hline Respiratory syncytial virus & 2 & 3 & \\
\hline Rhinovirus/enterovirus & 10 & 21 & .74 \\
\hline $\begin{array}{l}\text { Positive fecal PCR results as a } \\
\text { percentage of total fecal PCR samples } \\
\text { taken from hematology patient cohort }\end{array}$ & $\begin{array}{l}6 \text { of } 75 \\
(8.00)\end{array}$ & $\begin{array}{l}5 \text { of } 74 \\
(6.76)\end{array}$ & .77 \\
\hline Campylobacter spp & 0 & 1 & \\
\hline Clostridium difficile & 4 & 1 & \\
\hline Giardia intestinalis & 1 & 1 & \\
\hline Norovirus & 1 & 1 & \\
\hline Salmonella spp & 0 & 1 & \\
\hline $\begin{array}{l}\text { Positive blood cultures as a \% } \\
\text { of total blood cultures taken } \\
\text { from hematology patient cohort }\end{array}$ & $\begin{array}{c}27 \text { of } 826 \\
(3.27)\end{array}$ & $\begin{array}{c}28 \text { of } 822 \\
(3.41)\end{array}$ & .88 \\
\hline Gram-positive bacteria ${ }^{a}$ & 10 & 13 & .52 \\
\hline Enterococcus faecium & 7 & 4 & \\
\hline Staphylococcus aureus & 0 & 3 & \\
\hline $\begin{array}{l}\text { Staphylococcus spp (coagulase } \\
\text { negative) }\end{array}$ & 1 & 3 & \\
\hline Other gram-positive bacteria & 2 & 3 & \\
\hline Gram-negative bacteria $^{a}$ & 19 & 19 & .99 \\
\hline Escherichia coli & 6 & 10 & \\
\hline Klebsiella spp & 3 & 7 & \\
\hline Pseudomonas aeruginosa & 3 & 0 & \\
\hline Enterobacter cloacae complex & 2 & 0 & \\
\hline Other gram-negative bacteria & 5 & 2 & \\
\hline
\end{tabular}

Note. PCR, polymerase chain reaction.

${ }^{a}$ Includes cultures in which $>1$ organism was isolated.

\section{Discussion}

The percentage of positive respiratory PCR results was significantly lower in 2020 than 2019, when the hospital implemented changes in infection control practices and visitor restrictions during the COVID-19 pandemic (Appendix 1 online). The notable increase in the rates of rhinovirus/enterovirus in 2020, however, may be due to reduced activity of alcohol-based hand sanitizers on nonenveloped viruses. ${ }^{3}$

Blood cultures and fecal PCR results did not show statistically different rates of infection; these were mostly commensals or infections less affected by droplet precaution measures implemented during the pandemic.

Although similar numbers of blood cultures and fecal PCR samples were taken each year, we attribute the increased number of respiratory PCR samples taken in 2020 to heightened awareness for testing during the pandemic. Greater than 75\% of all positive respiratory PCR samples were taken within 48 hours of admission, and although the results are unlikely to solely reflect community exposure (ie, our hematology patients frequently attend day treatment centers and other hospital services), a limitation is the difficulty in accounting for the expected reduction of circulating non-COVID-19 respiratory viruses in the community due to government restrictions and public behavior.

In hematology patients, viral infections are an important cause of morbidity and mortality. ${ }^{4,5}$ Therefore, increased awareness and utilization of infection control measures is vital for reducing rates of infection. Although our study was retrospective, we found a reduced rate of viral respiratory infection when stricter measures were in place at our hospital. This is a useful indication of their effectiveness, and incorporation into general hematology infection control can be considered. Further studies are warranted to assess the extent and duration of the impacts resulting from increased use of hand-sanitizer, limiting ward visitation, and social distancing on reducing infections within the hematology patient population.

\section{Acknowledgments.}

Financial support. No financial support was provided relevant to this article.

Conflicts of interest. All authors report no conflicts of interest relevant to this article.

\section{References}

1. Chow A, Hein AA, Kyaw WM. Unintended consequence: influenza plunges with public health response to COVID-19 in Singapore. J Infect 2020;81(2): e68-e69.

2. Yang K, Sheng Y, Huang C, et al. Clinical characteristics, outcomes, and risk factors for mortality in patients with cancer and COVID-19 in Hubei, China: a multicenter, retrospective, cohort study. Lancet Oncol 2020;21:904-913.

3. Kampf G. Efficacy of ethanol against viruses in hand disinfection. J Hosp Infect 2018;98:331-338.

4. Khanna N, Widmer AF, Decker M, et al. Respiratory syncytial virus infection in patients with hematological diseases: single-center study and review of the literature. Clin Infect Dis 2008;46:402-412.

5. Wade JC. 2006. Viral infections in patients with hematological malignancies. In: The ASH Education Program Book. Washington, DC, American Society of Hematology: 2006:368-374. 


\section{Appendix 1. Restrictions during the COVID-19 Pandemic Within the Hospital Network and the State From January 24 to May 23, 2020}

\begin{tabular}{|c|c|c|}
\hline Date & Monash Health & $\begin{array}{l}\text { State of Victoria, } \\
\text { Australia }\end{array}$ \\
\hline January 24, 2020 & \multicolumn{2}{|c|}{$\begin{array}{l}\text { First COVID positive patient in Australia is admitted } \\
\text { at Monash Health. }\end{array}$} \\
\hline $\begin{array}{l}\text { February 10, } \\
2020\end{array}$ & $\begin{array}{l}\text { Hand hygiene posters } \\
\text { produced in the } 10 \text { non- } \\
\text { English languages most } \\
\text { commonly spoken by } \\
\text { patients }\end{array}$ & \\
\hline $\begin{array}{l}\text { February 21, } \\
2020\end{array}$ & $\begin{array}{l}\text { Surgical masks provided } \\
\text { in the ED for all patients } \\
\text { with flu-like symptoms }\end{array}$ & \\
\hline March 4, 2020 & $\begin{array}{l}\text { Campaign to refresh PPE } \\
\text { knowledge launched } \\
\text { including videos, online } \\
\text { and in-person modules }\end{array}$ & \\
\hline March 12, 2020 & $\begin{array}{l}\text { World Health Organization } \\
\text { COVID-19 crisis a pandemic }\end{array}$ & WHO) names the \\
\hline March 15, 2020 & $\begin{array}{l}\text { Visitors limited to } 2 \text { per } \\
\text { patient during a specified } \\
\text { time period on the } \\
\text { hematology ward }\end{array}$ & $\begin{array}{l}\text { International travelers } \\
\text { must quarantine on } \\
\text { arrival for } 2 \text { weeks. }\end{array}$ \\
\hline March 16, 2020 & & $\begin{array}{l}\text { Gatherings of }>500 \\
\text { people are banned. }\end{array}$ \\
\hline March 18, 2020 & $\begin{array}{l}\text { Staff-only testing clinics } \\
\text { open }\end{array}$ & \\
\hline March 19, 2020 & $\begin{array}{l}\text { Campaign launched to } \\
\text { focus on the WHO 'Five } \\
\text { Moments of Hand } \\
\text { Hygiene' }\end{array}$ & \\
\hline March 20, 2020 & $\begin{array}{l}\text { Most volunteers told to } \\
\text { stop coming to the } \\
\text { hospital }\end{array}$ & $\begin{array}{l}\text { Australian border is } \\
\text { closed to nonresidents. }\end{array}$ \\
\hline March 23, 2020 & $\begin{array}{l}\text { Hematology ward closed } \\
\text { to all visitors; staff must } \\
\text { work from home } \\
\text { where able. }\end{array}$ & \\
\hline March 24, 2020 & & $\begin{array}{l}\text { Lockdown starts, } \\
\text { people must not leave } \\
\text { home except for } \\
\text { essential purposes. } \\
\text { International and } \\
\text { domestic travel is } \\
\text { severely restricted. }\end{array}$ \\
\hline March 29, 2020 & $\begin{array}{l}\text { Other wards only allow } \\
1 \text { visitor for } 1 \mathrm{~h} \text { per day } \\
\text { (the hematology ward } \\
\text { remains closed). All } \\
\text { visitors screened on } \\
\text { entry. }\end{array}$ & $\begin{array}{l}\text { Gatherings are limited } \\
\text { to } 2 \text { people. }\end{array}$ \\
\hline March 30, 2020 & $\begin{array}{l}\text { Hematology day treat- } \\
\text { ment unit is moved off } \\
\text { the ward to a separate } \\
\text { building. }\end{array}$ & \\
\hline April 9, 2020 & $\begin{array}{l}\text { All visitors and staff } \\
\text { have body temperatures } \\
\text { checked on entry to the } \\
\text { building. }\end{array}$ & \\
\hline
\end{tabular}

(Continued)

\begin{tabular}{lll}
\hline Date & Monash Health & $\begin{array}{l}\text { State of Victoria, } \\
\text { Australia }\end{array}$ \\
\hline April 12, 2020 & $\begin{array}{l}\text { Staff encouraged to wear } \\
\text { scrubs while at work. }\end{array}$ \\
\hline April 26, 2020 & & $\begin{array}{l}\text { COVIDSafe app is } \\
\text { released. }\end{array}$ \\
\hline April 29, 2020 & $\begin{array}{l}\text { Asymptomatic staff } \\
\text { encouraged to get tested } \\
\text { at new clinics opened. }\end{array}$ \\
\hline May 8, 2020 & $\begin{array}{l}\text { Hand hygiene audit tar- } \\
\text { gets achieved for March } \\
\text { and April. }\end{array}$ \\
\hline
\end{tabular}

\section{Appendix 2}

The respiratory pathogens 12 assay tests for the following organisms:

1. Adenovirus

2. Bordetella pertussis

3. Human metapneumovirus

4. Influenza A virus

5. Influenza $B$ virus

6. Parainfluenza viruses $-1,-2,-3$, and -4

7. Picornavirus (rhinovirus/enterovirus)

8. Respiratory syncytial virus

9. Severe acute respiratory coronavirus virus 2 (SARS-CoV-2)

The fecal pathogens B assay tests for the following organisms:

1. Adenovirus

2. Astrovirus

3. C. difficile

4. Campylobacter jejuni/coli/doyeli

5. Cryptosporidium spp

6. Entamoeba histolytica

7. Giardia intestinalis

8. Norovirus

9. Rotavirus

10. Salmonella $s p p$

11. Sapovirus

12. Shiga toxin 1 and 2

13. Shigella $s p p$

14. Yersinia $s p p$

The Bactec FX (BD Diagnostics) blood culture system was used. The following organisms were defined as contaminants if isolated in a single positive culture:

1. Coagulase-negative Staphylococcus

2. Bacillus spp

3. Propionibacterium/Cutibacterium spp

4. Viridans streptococci

5. Corynebacterium spp

6. Kocuria spp

7. Micrococcus spp

In cases of a repeat positive blood culture within 7 days with the same organism, the isolate was defined as pathogen. 